\title{
SYNTHETIC PEPTIDE INHIBITORS OF TRANSPEPTIDATION BY THE EXOCELLULAR DD-CARBOXYPEPTIDASE-TRANSPEPTIDASE FROM ACTINOMADURA R39
}

\author{
Harold R. PERKINS, Jean-Marie FRERE ${ }^{+}$and Jean-Marie GHUYSEN ${ }^{+}$ \\ Department of Microbiology, University of Liverpool, Liverpool L69 3BX, England and ${ }^{+}$Service de Microbiologie, \\ Faculté de Médicine, Institut de Botanique, Université de Liège, Sart Tilman, 4000 Liège, Belgium
}

Received 11 November 1980

\section{Introduction}

The penicillin-sensitive exocellular carboxypeptidases-transpeptidases of Actinomycetes have been extensively studied as models of peptidoglycan construction and modification in relation to their mode of enzyme action and their mechanism of inhibition by $\beta$-lactam antibiotics $[1,2]$. The enzyme from Actinomadura $\mathrm{R} 39$ has been purified to homogeneity [3] and is known to catalyse hydrolysis of the C-terminal D-alanyl-D-alanine peptide bound in natural and synthetic substrates (e.g., $\mathrm{Ac}_{2}-\mathrm{L}-\mathrm{Ly}$-D-AlaD-Ala) or, in the presence of a suitable acceptor, to perform transpeptidation in which an acceptor moiety such as meso-diaminopimelic acid $\left(\mathrm{A}_{2} \mathrm{pm}\right)$ replaces the terminal D-alanine [4]. The amount of transpeptidation relative to carboxypeptidase action in a particular digest was highly sensitive to the concentration of a 'natural' acceptor:

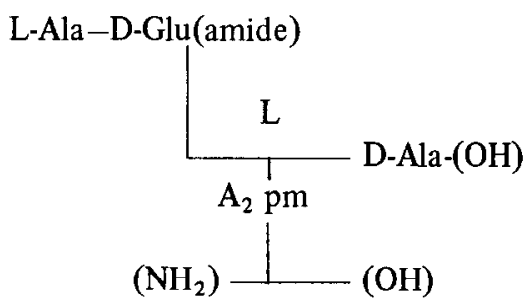

where the new peptide bound was formed at the point indicated by $\left(\mathrm{NH}_{2}\right)$. It was found that the amount of transpeptidation product reached a sharp maximum at acceptor-donor molar ratios between 1 and 3, depending on the absolute donor concentration, and then declined roughly in parallel with an inhibition by increasing acceptor concentration of both the hydrolytic and transpeptidase actions of the enzyme [4]. Although certain synthetic peptides inhibited the soluble DD-carboxypeptidases of other Actinomycetes (Streptomyces strains albus $\mathrm{G}$ and R61) [5] c.g., Ac-D-Ala-D-Glu, Ac-Gly-D-AlaD-Glu and disuccinyl-L-Lys-D-Ala--D-Glu, these inhibitors were without effect on the carboxypeptidase of Actinomadura R39 [5]. Other peptides, such as $\epsilon$-glycyl- $\alpha$-acetyl-L-lysine were not acceptors for the R39 enzyme, since this requires its acceptor to possess an amino group in $\alpha$-position to a free carboxyl group, but with the R61 enzyme they served as acceptors and the proportion of transpeptidation of donor relative to its hydrolysis passed through a fairly sharp maximum as acceptor concentration increased [6]. This paper describes the effects of this and other synthetic, non-acceptor peptides on the relative proportion of transpeptidation and hydrolysis performed by the R39 enzyme with the synthetic donor $\mathrm{Ac}_{2}$-L-Lys-D-Ala-D-Ala and either meso-A $\mathrm{A}_{2} \mathrm{pm}$ or glycine as acceptor.

\section{Materials and methods}

These were essentially as in [6]. The enzyme preparation from Actinomadura $\mathrm{R} 39$ and the sources of most of the peptides werc as before. The peptides $\epsilon$-D-Ala- $\alpha$-Ac-L-Lys and $\epsilon$-(3-aminopropionyl)$\alpha$-Ac-L-Lys ( $\epsilon$ - $[\beta$-Ala]- $\alpha$-Ac-L-Lys) were synthesized by a route similar to that described for $\epsilon-\mathrm{Gly}-\alpha-\mathrm{Ac}-$ L-Lys [6]. The labelled donor was $\left[{ }^{14} \mathrm{C}\right] \mathrm{Ac}_{2}-\mathrm{L}-\mathrm{Lys}-$ D-Ala-D-Ala, $1.75 \mathrm{mM}$ and the acceptor was meso$\mathrm{A}_{2} \mathrm{pm}$. In some experiments $\left[{ }^{14} \mathrm{C}\right] \mathrm{Gly}$ was the acceptor and unlabelled donor was used. Transpeptidation assays in $30 \mu 1$ final vol. were conducted at $\mathrm{pH} 8$ in $16.7 \mathrm{mM}$ phosphate buffer, except where otherwise 
stated, at $37^{\circ} \mathrm{C}$ with incubation times of $1 \mathrm{~h}$, or $10 \mathrm{~min}$ in experiments where the initial rate of reaction was required. In some experiments the phosphate buffer was increased to $0.5 \mathrm{M}$, since this high ionic strength was known to favour transpeptidation by the R39 enzyme [4]. Molar ratios of acceptor to donor were either $1: 1$ or $10: 1$ as stated. Unchanged donor and the products yielded by carboxypeptidase or transpeptidase action were separated by highvoltage electrophoresis at $\mathrm{pH} 6.5$ and their radioactivity measured.

\section{Results and discussion}

The model transpeptidation reaction:

$$
\begin{gathered}
\mathrm{Ac}_{2}-\mathrm{L}-\mathrm{Lys}-\mathrm{D}-\mathrm{Ala}-\mathrm{D}-\mathrm{Ala}+\text { meso-A } \\
\mathrm{Ac}_{2}-\mathrm{pm}-\mathrm{pys}-\mathrm{D}-\mathrm{Ala}-(\mathrm{D}) \text { meso-A } \\
\longrightarrow
\end{gathered}
$$

was performed in vitro by a soluble enzyme from Actinomadura R39 $[4,6]$. We studied the effect upon this reaction of various peptides that were neither

Table 1

\begin{tabular}{|c|c|c|c|c|c|c|c|}
\hline \multirow{2}{*}{$\begin{array}{c}\text { Phosphate } \\
\text { buffer } \\
\mathrm{mM}\end{array}$} & \multirow{2}{*}{$\begin{array}{l}\text { Acceptor: } \\
\text { donor } \\
\text { molar } \\
\text { ratio }\end{array}$} & \multirow{2}{*}{$\begin{array}{c}\text { Arded } \\
\text { peptide }\end{array}$} & \multirow{2}{*}{$\begin{array}{l}\text { Peptide: } \\
\text { donor } \\
\text { molar } \\
\text { ratio }\end{array}$} & \multirow{2}{*}{$\begin{array}{l}\text { Percentage of donor } \\
\text { transpeptidation } \\
\text { product }(T)\end{array}$} & \multirow{2}{*}{$\begin{array}{l}\text { converted to } \\
\begin{array}{l}\text { hydrolysis } \\
\text { product (H) }\end{array}\end{array}$} & \multirow{2}{*}{$\begin{array}{l}\text { Percentage } \\
\text { inhibition of } \\
\text { transpeptidation }\end{array}$} & \multirow[t]{2}{*}{$\mathrm{T} / \mathrm{H}$} \\
\hline & & & & & & & \\
\hline \multirow[t]{4}{*}{16.7} & $1: 1$ & None & & 12.3 & 69.8 & & 0.18 \\
\hline & & $c-G 1 y-\alpha-A c-L-L y s$ & $1: 1$ & 9.0 & 76.0 & 27 & 0.12 \\
\hline & & & $5: 1$ & 4.8 & 82.3 & 60.8 & 0.06 \\
\hline & & & $10: 1$ & 2.7 & 83.3 & 79.2 & 0.03 \\
\hline \multirow[t]{5}{*}{16.7} & $1: 1$ & None & & 14.7 & 65 & & 0.23 \\
\hline & & $\varepsilon-G l y-\alpha-A c-L-L y s$ & & & & & \\
\hline & & methyl ester & $10: 1$ & 9.6 & 70.5 & 35 & 0.14 \\
\hline & & $\varepsilon-G l y-\alpha-A c-L-L y s$ & & & & & \\
\hline & & amide & $10: 1$ & $7 \cdot 7$ & 71.5 & 48 & 0.11 \\
\hline \multirow[t]{3}{*}{16.7} & $1: 1^{a}$ & None & & 9.9 & $37 \cdot 9$ & & 0.26 \\
\hline & & $\alpha-A c-L-L y s$ & $10: 1$ & 5.8 & 22.2 & $41 \cdot 4$ & 0.26 \\
\hline & & E-aminohexanoic acid & $10: 1$ & 9.2 & 37.6 & 7.5 & 0.24 \\
\hline \multirow[t]{3}{*}{16.7} & $1: 1$ & None & & 13.0 & 60.8 & & 0.21 \\
\hline & & $\therefore-n-A 1 a-\alpha-A c-1 \cdot-1 . y a$ & $10: 1$ & 4.5 & 77.3 & 67.6 & 0.06 \\
\hline & & $\varepsilon-[\beta-A 1 a]-\alpha-A c-L-L y s$ & $10: 1$ & 2.6 & 66.1 & 81.6 & 0.04 \\
\hline \multirow[t]{3}{*}{16.7} & $1: 1$ & None & & 11.3 & 78.6 & & 0.14 \\
\hline & & $G 1 y-G 1 y-G 1 y$ & $10: 1$ & $4 \cdot 5$ & $84 \cdot 5$ & 60.4 & 0.05 \\
\hline & & $G l y-G l y-G l y-G l y$ & $10: 1$ & 6.2 & 83.0 & $45 \cdot 3$ & 0.07 \\
\hline \multirow[t]{6}{*}{$16 \cdot 7$} & $1: 1$ & None & & 13.1 & 68 & & 0.19 \\
\hline & & $G 1 y-G 1 y$ & $1: 1$ & 12.3 & 71.8 & 8 & 0.17 \\
\hline & & & $5: 1$ & 9.8 & $75 \cdot 4$ & 26.8 & 0.13 \\
\hline & & & $10: 1$ & 8.2 & $75 \cdot 3$ & 38.8 & 0.11 \\
\hline & & G1y-L-Ala & $9: 1$ & 8.1 & 73.9 & 39.5 & 0.11 \\
\hline & & $G l y-L-G l u$ & $10: 1$ & 5.8 & 77 & 56.7 & 0.08 \\
\hline \multirow[t]{2}{*}{16.7} & $10: 1$ & None & & $47 \cdot 7$ & 2.8 .8 & & 1.66 \\
\hline & & $\varepsilon-D-A l a-\alpha-A c-L-L y s$ & $10: 1$ & 25.9 & 43.7 & 45.8 & 0.59 \\
\hline \multirow[t]{2}{*}{16.7} & $10: 1$ & None & & 41.5 & 22.6 & & 1.83 \\
\hline & & $\varepsilon-[\beta-A 1 a]-\alpha-A c-L-L y s$ & $10: 1$ & 21.9 & 37.1 & $47 \cdot 3$ & 0.59 \\
\hline \multirow[t]{2}{*}{16.7} & $10: 1^{a}$ & None & & $31 \cdot 4$ & 15.2 & & 2.06 \\
\hline & & $c-L-A \mid A-a-A c-1,-L y a$ & $10: 1$ & 36.2 & 15.5 & -15.2 & 2.33 \\
\hline \multirow[t]{5}{*}{500} & $10: 1$ & None & & 67.5 & 20.7 & & 3.25 \\
\hline & & $C-G \operatorname{ly}-a-A c-L-L y g$ & $1: 1$ & 66 & 21.7 & 2.2 & 3.04 \\
\hline & & & $5: 1$ & 60.1 & 28.5 & 10.9 & 2.11 \\
\hline & & & $10: 1$ & 53.7 & 31.5 & 20.5 & 1.70 \\
\hline & & & $20: 1$ & 47.6 & 37.6 & 29.5 & 1.27 \\
\hline
\end{tabular}

Inhibition of in vitro transpeptidation by added peptides

\footnotetext{
a $A$ lower concentration of enzyme was used in this experiment
}

Conditions: donor, $\mathrm{Ac}_{2}-\mathrm{L}-\mathrm{Lys}-\mathrm{D}-\mathrm{Ala}-\mathrm{D}-\mathrm{Ala}$; acceptor, meso-A $\mathrm{A}_{2} \mathrm{pm}$; incubation, $1 \mathrm{~h}$ at $37^{\circ} \mathrm{C}(\mathrm{pH}$ ) 
donors nor acceptors but were structurally related to peptidoglycan fragments, in the hope that some light might be shed on possible mechanisms for localized control of peptidoglycan cross-linking. The results are shown in table 1 .

The analogous peptides $\epsilon$-Gly- $\alpha$-Ac-L-Lys, $\epsilon$-D-Ala $-\alpha$-Ac-L-Lys and $\epsilon$-[ $\beta$-Ala] $-\alpha$-Ac-L-Lys all inhibited transpeptidation without greatly affecting the hydrolytic action of the enzyme, each causing $67-82 \%$ inhibition when present at 10 -times the concentration of the donor or acceptor, which were present in equimolar proportion. The extent to which the various structural features of these peptides were important in their inhibitory action was examined by using other partial analogues. Of simple dipeptides Gly-Gly had the least effect ( $40 \%$ inhibition at 10 -fold inhibitor/donor ratio) and Gly-L-Glu the most (57\%). Increasing the length of the polyglycine chains showed that Gly-Gly -Gly was more effective • (60\% inhibition) than Gly-Gly-Gly-Gly (45\%). Thus it seemed possible that the overall distance between the terminal amino and carboxyl groups might be of importance:

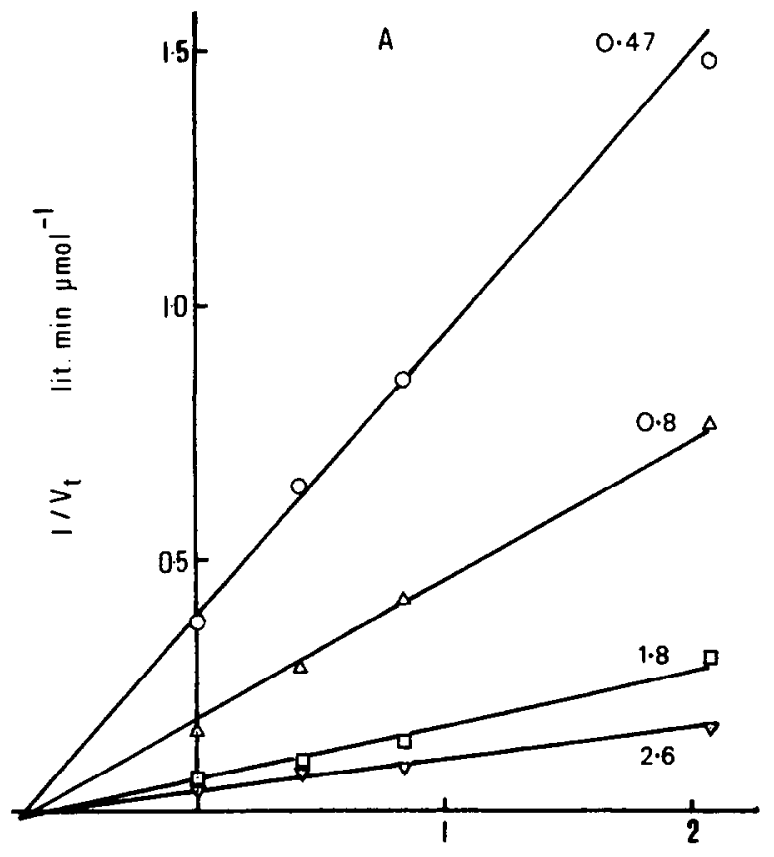

INHIBITOR CONCN.

\section{(cf. $\mathrm{NH}_{2} \mathrm{CH}_{2} \mathrm{CONHCH}_{2} \mathrm{CONHCH}_{2} \mathrm{COOH}$ and}

\author{
$\mathrm{NHCOCH}_{3}$ \\ $\mathrm{NH}_{2} \mathrm{CH}_{2} \mathrm{CONIICH}_{2} \mathrm{CH}_{2} \mathrm{CH}_{2} \mathrm{CHCOOH}$ ).
}

The shorter partial analogue $\alpha$-Ac-L-Lys was less effective and $\epsilon$-aminohexanoic acid (the same thing without the acetamido substituent at $\mathrm{C}_{2}$ ) was almost without effect, possibly implying a role for a peptide or amide bond in the proximity of the carboxylterminus. It should be noted that, alone among all the substances tested, $\alpha$-Ac-L-Lys inhibited hydrolytic action to almost exactly the same extent as transpeptidation.

The effect of the free carboxyl group itself was studied by using the methyl ester and the amide of $\epsilon$-Gly- $\alpha$-Ac-L-Lys. Both of these types of masking decreased the inhibitory effect of 40-50\%.

Some experiments were conducted with the inhibitor/donor ratio $10: 1$ as before, but with acceptor/ donor 10:1 instead of $1: 1$. Under these conditions the ratio of transpeptidation in the control samples relative to hydrolysis of donor lay between 1.7 and 2,

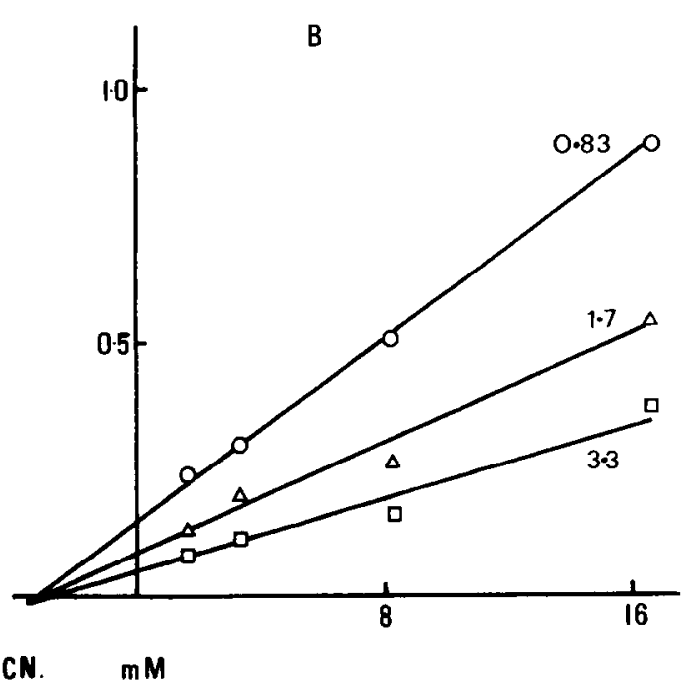

Fig.1. Dixon plots of inhibition of in vitro transpeptidation by synthetic peptides. The donor was Ac ${ }_{2}-\mathrm{L}-\mathrm{Lys}-\mathrm{D}-\mathrm{Ala}-\mathrm{D}-\mathrm{Ala}$. (a) Acceptor, meso- $\mathrm{A}_{2} \mathrm{pm}$. Acceptor/donor ratio 1:1. Inhibitor, $\epsilon-\mathrm{Gly}-\alpha-\mathrm{Ac}-\mathrm{L}-\mathrm{Lys}$. Donor/acceptor concentration (mM) is shown on the graph. (b) Acceptor, Gly; concentration (mM) varied and shown on the graph. Donor concentration constant (excess) 16.7 mM. Inhibitor, $\epsilon-[\beta-A l a]-\alpha-A c-L-L y s$. 
and the most effective inhibitors again produced extensive inhibition of transpeptidation while hydrolysis proportionately increased $(\mathrm{T} / \mathrm{H}$ decreased 3 -fold). Whereas $\epsilon$-D-Ala- $-\alpha$-Ac-L-Lys was active in this way, its configurational analogue $\epsilon$-L-Ala $-\alpha-A c-$ L-Lys was without effect. When transpeptidation in the controls was further promoted by the use of $500 \mathrm{mM}$ buffer [4], inhibition of transpeptidation and a corresponding increase in hydrolysis of donor still took place in the presence of $\epsilon$-Gly- $\alpha$-Ac-L-Lys ( $\mathrm{T} / \mathrm{H}$ again decreased 3 -fold).

The kinetics of the inhibition of transpeptidation by peptides were studied in experiments where the concentrations of either donor/acceptor together or acceptor alone were varied and the initial rate of reaction could be examined (shorter times and lower enzyme concentration). The Dixon plots in fig.1 show that inhibition was non-competitive in relation either to donor/acceptor or to acceptor alone, and that for $\epsilon$-Gly $-\alpha \cdot$ Ac-L-Lys (donor/acceptor concentration varied) and $\epsilon-[\beta-A l a]-\alpha-A c-L-L y s$ (acceptor concentration varied) the $K_{\mathrm{i}}$-values were $0.73 \mathrm{mM}$ and $3.5 \mathrm{mM}$, respectively. Similar experiments with only acceptor concentrations varied gave $K_{\mathrm{i}}$-values of I.5 mM for $\epsilon$-Gly- $\alpha$-Ac-L-Lys and $18.5 \mathrm{mM}$ for Gly-Gly-Gly.

The fact that the inhibitory peptides gave noncompetitive kinetics relative to both donor and acceptor implies that they were not functioning at the active site of the enzyme, but were rather involved in some allosteric action. This supports the notion, proposed [4], that part of the control of transpeptidation during the biosynthesis of peptidoglycan may be exerted by the proximity of relevant peptides. It remains to be seen whether the transpeptidation inhibitors used here will have effects on enzymes directly involved in the crosslinking of peptidoglycan.

\section{Acknowledgements}

We thank I. D. Bird and C. S. Gilbert for technical assistance. H. R. P. was in receipt of a Programme Grant from the Medical Research Council; J.-M. G. and J.-M. F. were supported in part by an Action Concertée financed by the Belgian State (convention no. 79784-I1), the Fonds de la Recherche Scientifique Médicale, Brussels (contract no. 3.4501.79) and the National Institutes of Health, Washington, DC (grant no. 2 R01 AI 13364-04).

\section{References}

[1] Ghuysen, J.-M. (1977) J. Gen. Microbiol. 101, 13.

[2] Ghuysen, J.-M. (1977) The bacterial DD-carboxypeptidase-transpeptidase enzyme system: A new insight into the mode of action of penicillin, University of Tokyo Press, Tokyo.

[3] Frère, J.-M., Moreno, R., Ghuysen, J.-M., Perkins, H. R., Dierickx, L. and Delcambe, L. (1974) Biochem. J. 143, 233.

[4] Ghuysen, J.-M., Leyh-Bouille, M., Campbell, J. N., Moreno, R., Frère, J.-M., Duez, C., Nieto, M. and Perkins, H. R. (1973) Biochemistry 12, 1243.

[5] Nieto, M., Perkins, H. R., Leyh-Bouille, M., Frère, J.-M. and Ghuysen, J.-M. (1973) Biochem. J. 131, 163.

[6] Perkins, H. R., Nieto, M., Frère, J. M., Leyh-Bouille, M. and Ghuysen, J.-M. (1973) Biochem. J. 131, 707. 